\title{
Meninos e Meninas de Rua: o que Sabem e como pensam*
}

\section{Clair Ribeiro Ziebell}

Universidade do Vale do Rio dos Sinos (Unisinos)

Fernando Becker

Universidade Federal do Rio Grande do Sul (UFRGS)

Busca esta investigação rastrear, num primeiro momento, o que sabem meninos e meninas de rua sobre família, educação-escola, riquezapobreza, saúde-doença, FEBEM, juizado, polícia, violência, saláriotrabalho, entre outros tópicos. Num segundo momento, busca investigar como pensam, isto é, sua capacidade organizadora desses saberes ou sua lógica. A análise doprimerio tópico revela expressões, sentimentos e comportamentos, como: aceitação, crítica, revolta, passividade, ironia, raiva, ódio, tristeza, afeto, desafeto, denúncia de perplexidade diante da realidade social. A análise do segundo, valendo-se de epistemologia genética piagetiana e da lógica formal, orienta-se pelas categorias: narrativa de ações, controle do tempo, fragmentos - totalidade, afirmação seguida de conjunção adversativa, o raciocínio hipotéticodedutivo, argumentação concatenada. Esta pesquisa procurou, pelas vias combinada da epistemologia genética piagetiana e da pedagogia freireana, delinear os pressupostos de um caminho capaz de recuperar o significado do processo de construção do conhecimento e da relação pedagógica fecunda, com vistas ao processo educacional escolar, em particular o de alfabetização, desses sujeitos.

-Determinados pelo subtítulo da pesquisa, dividimos este texto em duas partes: 1") o que sabem meninos e meninas de rua, redigido por Clair Ribeiro Ziebell, sob o título: "Do censo comum à conscientização possivel e, $2^{\mathrm{a}}$ ) como pensam, redigido por Fernando Becker, sob o título: "Lógica subjacente à fala de meninos e meninas de rua". Esta distinção impõe-se para que o leitor se situe numa ótica claramente interdisciplinar. Clair pensa o tema sob o ponto de vista dos movimentos sociais (MNMMR) e do serviço social. Fernando trabalha com a Epistemologia Genética piagetiana. A fecundação recíproca destas óticas, no sentido interdisciplinar, poderá ser feita pelo leitor. 


\section{Do senso comum à conscientização possível}

Em nossa atuação com meninos e meninas de rua de Porto Alegre, tínhamos em vista a sua organização. Neste sentido, o projeto "educador social de rua" aparecia como uma mediação necessária. Nosso suporte e retaguarda era constituído pelo Movimento Nacional de Meninos e Meninas de Rua (MNMMR), onde buscávamos subsídios pedagógicos e nos fortalecíamos como grupo, trocando experiências e, sobretudo, acumulando dados. Esta pesquisa visa à sistematização desses dados e à construção de conhecimento a partir deles, buscando, por este caminho, a melhor compreensão desse processo e das possibilidades e limites dessa organização nacional de meninos e meninas de rua. O projeto "educador social de rua" consiste numa prática educativa que se realiza no próprio espaço da rua, onde se encontram as crianças; materializa-se na figura do educador social de rua, que realiza, sistematicamente, em grupos, um trabalho de abordagens dos meninos(as), que com o decorrer do processo vai ganhando dinamicidade e evolui, num primeiro momento, para agrupar meninos e meninas, ajudá-los nas dificuldades do dia-a-dia, e, num segundo momento, pensar a organização para a defesa dos seus direitos. Em Porto Alegre, a comissão local do MNMMR executou o projeto, de 1987 a 1990 (Ziebell et al., 19-; Bulgarelli, 1987).

$\mathrm{Na}$ convivência nas ruas, nos encontros e nas entrevistas, deparamo-nos com as representações desses sujeitos sobre: família, educação-escola, riqueza-pobreza, saúde-doença, FEBEM (Fundação Estadual do Bem-Estar do Menor-RS), juizado, polícia, salário-trabalho, entre outras.

Dadas a riqueza e a complexidade dos conteúdos e nossas condições objetivas de trabalho, delimitamos nossa fala aos aspectos referentes à possibilidade de superação do senso comum. Este processo de ruptura com o senso comum tem por base nossa concepção teórica a respeito da tensão permanente que deve existir entre ação e reflexão. Teoricamente, utilizaremos as categorias de reprodução e resistência para 
a compreensão do processo que leva a conscientização, entendida como: 'Tomar posse da realidade... olhar mais crítico possível da realidade, que a desvela para conhecê-la e para conhecer os mitos que enganam e que ajudam a manter a realidade da estrutura dominante" (Freire, 1979a, p.29) ${ }^{1}$. Quanto ao pensamento de meninos e meninas sobre os temas já elencados, percebemos, em suas expressões, sentimentos e comportamentos como: aceitação, crítica, revolta, passividade, ironia, raiva, ódio, tristeza, afeto, desafeto e denúncia, dentre outros, denotando uma concepção de mundo impregnada de senso comum que, segundo a concepção de Gramsci (apud Maciel e Cardoso, 1989, p. 166), "é a forma de pensamento própria das massas, onde se encontram articuladas de maneira bizarra elementos da ideologia dominante e elementos surgidos de sua própria realidade de vida, expressando uma concepção de mundo ocasional e desagregada". Os momentos de lucidez que se evidenciam no senso comum representam as bases de uma nova e independente concepção, ou seja, constituem instituições de uma futura filosofia que será própria do gênero humano, mundialmente unificado.

Este núcleo positivo do senso comum é o que Gramsci (apud Maciel e Cardoso, 1989, p. 167) denomina de bom senso, ou seja, expressão embrionária de uma concepção de mundo própria que se manifesta na ação, merecendo ser desenvolvida em algo unitário e coerente.

$\mathrm{Na}$ fala das crianças aparecem as duas formas de pensamento que, para melhor compreensão, vamos relatar separadamente, embora constituem elementos de um único processo. Como elementos que reproduzem a ideologia dominante, destacamos as representações de alguns meninos e meninas em torno dos temas já elencados.

Referindo-se à escola, J.O.R., ao explicar porque não mais a freqüenta, assume para si e seu grupo familiar a responsabilidade do fracasso: "A escola era legal, mas eu não fiquei na escola por causa familiar. Chamavam meus pais no colégio, eu baguncei uma vez, daí (me) expulsaram". Outro menino dizia não aprender matemática, usando a

\footnotetext{
${ }^{1}$ Nosso entendimento dessas categorias neste estudo relaciona-se com as forma- de consciência social, sendo reprodução aquelas formas alienadas próprias da sociedade capitalista e resistentes à ruptura com o icnso comum e a alienação, base para o processo le conscientização. (Cf. Chaui, 1989, e Giroux, 1986.)
} 
expressão "porque não sou muito bom". Ele acabou abandonando a escola, por esse motivo, apesar de ir muito bem em outras disciplinas como português e ciências.

Sabemos que esta é a rotina de nosso projeto educacional convencional - público ou privado - que, apesar de inadequado à realidade da maioria de seus alunos, ainda provoca neles sentimentos de incompetência, fracasso, falta de inteligência ou de caráter. Percebe-se, também, o conformismo dos meninos e das meninas em ter de freqüentar escolas especiais, abertas ou alternativas, justificando como melhor este tipo de escola (algumas o são, outras não), como no depoimento de J.O.R. ao dizer que "a escola aberta" talvez fosse a saída porque possibilitaria "que eu estudasse comigo mesmo, só ia lá pegar os materiais". Porém, logo a seguir, continua: "outro jeito era com a professora passando no quadro, acho que podia ser melhor, mas não tenho esta chance". Dizem, também, que a escola é boa e, ao serem questionados sobre as razões de não permanecerem nela, explicam que é por decisão própria; no entanto, acrescentam que a professora era chata, violenta e que não gostavam dela. Vejamos um trecho da entrevista com a menina M.O.L., 12 anos:

E.:-M.O.L., tu achas a escola boa?

M.O.L.: - Acho, eu gosto de lá, mas...

E.:- Mas... não ficaste por quê?

M.O.L.: - Porque eu não queria. A professora era muito chata, eu não gostava dela.

E.: - O que ela fazia, que era chata?

M.O.L.: - Ah, tia, ela dava puxão de orelha na gente, puxão de cabelo na gente... eu não gostei de lá, eu estava quase... mas eu não fiquei lá, eu não sei escreve nem lê.

E.: - Tu gostarias de aprender a ler e escrever?

M.O.L.: - Gostaria. Ah, tia, aquele dia a senhora falou que ia botar nóis no cursinho. Agora não tem mais cursinho, né, tia, a FEBEM incendiou ne?!!

Percebe-se na fala de M.O.L., contradição e conformismo. Contradição quando afirma que a escola é boa, que saiu porque quis, e, ao mesmo tempo, denuncia agressões sofridas pela professora da qual 
afirma não ter gostado. Porém, nao relaciona sua saída com o comportamento da professora. Conformismo porque, apesar de não ter aprendido a ler e escrever, embora tenha vontade de aprender, a menina sai da escola e não se rebela contra a situação. A contradição e o conformismo são conseqüências da atuação discriminatória da escola que, entre outras instituições, é uma das veiculadoras da ideologia dominante.

Ainda ilustrando um pouco mais as conseqüências dessa dominação, citamos um relato, feito em dezembro de 1991, em reunião de avaliação de programas que atuam com meninos e meninas de rua, em Porto Alegre. Uma educadora explicava que às vezes se torna dificil detectar quando uma criança está alfabetizada, porque ela não lê na frente da educadora ou colegas, escondendo por algum tempo que está lendo, até ser surpreendida lendo, em algum canto afastado, ou fazendo alguma observação que demonstra mudança significativa em seu processo de aprendizagem. Este processo traduz a insegurança decorrente do sentimento interiorizado pelas crianças de que não são capazes, são pouco inteligentes, doentes, enfim, impossibilitadas de aprender como os demais colegas, o que faz com que duvidem quando este "prognóstico" não se confirma.

Perguntamos: até quando continuaremos coniventes com essa situação, enquanto nossas crianças acabam nas ruas, tendo a escola da "vida" ou da "morte" (?) como única alternativa de aprendizado?

Alguns meninos e meninas justificam até atos de violência contra eles, como, por exemplo, esta opinião em torno da chamada "Operação Papai Noel" (operação planejada e executada pela Brigada Militar para conservar afastados meninos de rua da zona mais movimentada do comércio de Porto Alegre, na época de compras natalinas): "É pro Natal ficar mais alegre, mais feliz, pras pessoas que não cheiram, não roubam, não são violentas". Percebe-se o quanto a ideologia dominante é reproduzida e quão grande é sua capacidade de se colocar como única e verdadeira para toda a população, levando os indivíduos a aceitarem que os que não se "enquadram" a determinados tipos, modelos, são prejudiciais, devem ser afastados do convívio dos ditos normais, restando a atitude conformista apoiada na explicação de que sempre foi assim. 
Este tipo de comportamento é reforçado por paradigmas funcionais que ao interpretarem a realidade o fazem de forma unilateral e mascarada, apontando como disfunções aquelas contradições que viabilizam a exploração e a dominação da grande maioria da população. Perguntamonos quão normais e funcionais são as pessoas e organizações que, em nome do "bem-estar" e da "tranqüilidade" de uma elite, prendem, surram, discriminam, matam, negando um mínimo de respeito às crianças que, já antes de nascer, têm negados seus direitos à habitação, saúde, alimentação, educação e tantos outros direitos. Perguntamos, também, quão normal é uma sociedade que vai mais além, exterminando em massa suas crianças e seus adolescentes quando estes ousam passar do conformismo à resistência, optando pelo confronto e reivindicação dos direitos que thes são negados. Esta legitimação da violência se estende, também, à família, como se percebe no discurso dos meninos e das meninas que, apesar de a terem abandonado, a defendem e a justificam, mesmo quando ela responde a eles com violência. Chegam a manifestar, até, a vontade de retornar à família, quando estiverem em melhor situação (emprego, escola, sem drogas). Isto fica claro na afirmação de A.J.O.: "Já levei batida, até de minha avó. Ela me xinga e eu fico quieto porque ela é mais velha. Acho legal que ela me dá conselho pra mim não usá mais droga, pra começa a trabalha, mas eu não consigo atende o conselho dela. Eu gosto muito da minha avó." O mesmo acontece na fala da A.L.B.: "Eu fico na base de dois, treis ano sem í em casa. Daí, eu fico na base de meia hora só em casa e saio fora, sabe. Não consigo agüenta fica em casa... Então eu tenho este remorso, então eu não consigo fica em casa, né dona, por isso."

Nesses depoimentos nota-se que a familia, por mais "disfuncional" que pareça, tenta exigir dois filhos comportamentos socialmente aceitos como: estudar, trabalhar, não usar drogas, não roubar, mesmo que até convivam e sobrevivam do uso da droga, do roubo que a criança faz ou traz para casa. É um comportamento ambivalente: pune e usufriu daquilo que ocasionou a punição. Esta ambivalência repercute negativamente na criança que não consegue ter um referencial forte o suficiente para nortear sua ação, expressando gratidão, mesmo que implícita, pela ação que teoricamente é condenada. 
A canção "Meu Guri", de Chico Buarque de Holanda ilustra muito bem nossa reflexão:

Olha aí/é o meu guri, olha aí,/é o meu guri/Ele chega, chega suado e veloz do batente./Traz sempre um presente pra mim encabular./Tanta corrente de ouro seu moço,que haja pescoço pra enfiar./Me trouxe uma bolsa/já com tudo dentro,/chave, caderneta, terço e patuá./Um lenço e uma penca de documento/pra finalmente eu me identificar...

A sensibilidade do artista dá conta da realidade desses meninos que, como tantos outros meninos que habitam as ruas do país, saem de casa em busca de melhores condições de vida, por causa da violência de avós, mães, padrastos. Fogem da violência familiar e acabam encontrando, nas ruas, outra violência mais refinada, direta e radical, que tem levado, não raras vezes, até a morte. Além disso, também entre eles mesmos, reproduzem atos violentos, como acontece nas brincadeiras, competições, trabalho ou, ainda, contra a população que lhes é hostil. Esta violência é, também, reprodução da violência social, econômica, política e cultural, violência da qual a sociedade brasileira é, historicamente, mentora e maestra.

A fala dos meninos e das meninas aponta também para o outro lado: o do inconformismo e da resistência a todo tipo de violência sofrida, esboçando sinais de uma nova consciência e de um conseqüente engajamento na luta pela transformação dessa realidade. Trata-se de uma participação, ainda tímida, mas que avança progressivamente para um processo de organização mais amplo.

Ao refletirmos sobre as formas de resistência, forjadas pelas crianças e pelos adolescentes, faz-se necessário pontuar algumas questões iniciais que norteiam nossa reflexão, a saber:

1. Que o modo de vida desses meninos e dessas meninas por si só já dá conta da força que possuem e de como na luta cotidiana resistem à fome, à doença, ao desamor, à violência e à discriminação, e como encontram formas criativas e lúdicas para enfrentar as várias situações com as quais se deparam: tanto agrupando-se, criando gírias que praticamente substituem o vacabulário considerado correto, tanto trocando 
informações de seu interesse (como a situação das instituições de assistência que freqüentam, polícia, pessoas novas que se aproximam do espaço que ocupam) ou testando relacionamentos e confianças. Este entendimento, no entanto, não significa de nossa parte uma concepção basista, romântica, que confia aos meninos e às meninas um poder que não possuem e um saber que prescinde do educador e de outros segmentos que venham em defesa dos seus interesses. Nossa convivência com eles, se algo teve de "romântica", constituiu-se pela relação abertas e amorosa que sempre estabelecemos com eles e que em geral foi recíproca. De resto, presenciamos a mesma violência, sentimos a mesma angústia, ainda que em graus menores, um vez que não vivemos nas ruas, apenas ouvimos suas histórias, compartilhamos alegrias, mas sobretudo anseios e medos. Também organizamos formas de defesa e denúncia a partir dos dados da realidade colhidos junto aos mesmos. Algumas vezes também nós, educadores, fomos perseguidos, discriminados e levados de camburão para a delegacia, tendo como culpa o fato de sairmos em defesa das crianças violentas pela polícia. Mesmo assim, não conseguimos avaliar a dimensão desses atos na vida das crianças porque esta perseguição contra nós não é contínua e, ainda, porque, devido a nossa própria condição social, possuímos instrumentos de defesa mais respeitados e também a nossa condição de adultos capazes de elaborar melhor essas situações, embora algumas "marcas" permaneçam.

2. Nossa convivência com os meninos e as meninas de rua nos fez sentir, como refletiu Paulo Freire com educadores de rua em São Paulo, "em eterno pasmo pedagógico", desde o perguntar-se "o que fazer?", "como fazer?", até a incredulidade, a dificuldade de compreender como crianças de 3, 4 anos de idade conseguem sobreviver em condições que poucos adultos suportariam.

O que sente uma criança que, muito cedo, tem a rua como único espaço transitável está contido na história que A.N.D. contou de sua vida:

"Este é mais um menininho de rua que está atirado, perdido, abandonado. Eu, um menininho de apenas 8 anos de idade, que não tenho onde morar a não ser atirado pelos cantos da cidade, tendo que passar frio e fome. Que não tenho onde comer a não ser batendo de porta em 
porta, pedindo ao menos um pedacinho de pão ou um restinho de comida para mim. Ninguém gosta de mim, ninguém me dá atenção. Aqueles caras policiais só vêm pra me dar em mim. Até hoje ninguém sorriu pra mim e eu não pude sorrir pra ninguém. Sou triste, sozinho, sou quieto!!"

Não ousamos comentar, neste momento, essa fala, deixando a critério do leitor a interpretação e os questionamentos sobre essa dolorosa realidade com a qual a maioria da sociedade convive serenamente.

Voltando a nossa reflexão sobre as formas de resistência, vamos encontrar, nas falas dos meninos e das meninas, elementos que anunciam que, no seio das mesmas instituições que os oprimem e os dominam ideologicamente, se forjam espaços contraditórios que possibilitam a formação de uma contra-ideologia. Espaços esses que, ao propiciarem o encontro com alguns educadores que não compactuam com o autoritarismo institucional e que vêem nos meninos e nas meninas o sujeito, o cidadão, a criança, o filho da classe trabalhadora, contribuem pela presença reflexiva, solidária e educativa. Esta presença leva à ruptura com o senso comum e, a médio e a logo prazos, à conscientização. Conscientizados, podem eles próprios defender seus direitos e engajar-se na luta mais ampla pela transformação da sociedade, como articuladores de seus interesses de classe. Isto se percebe nos encontros e entrevistas onde expressam opiniões que representam crítica e negação dos papéis desempenhados pelas várias instituições, apontando suas contraduções, seus limites e até suas alternativas, mesmo que essa crítica, num primeiro momento, tenha como único espaço alternativo a rua.

Reinaldo Bulgarelli (19-), educador de rua em São Paulo, escreve: "é importante percebermos que não são apenas carências, misérias e necessidades, mas também potencialidades. Não estão nas ruas apenas esperando ajuda, mais já saíram à luta; não se conformam com o que possuem e não aceitam tudo pronto, pois querem participar".

Como exemplo de que estão nas ruas também pelo inconformismo, ouvimos A.L.B., falando sobre a vida na sua família: "Bom, a vida a gente levava devagarinho, era meio chata. É que, às veis, faltava coisa. Eu tinha que lutar muito, trabalhar demais". Para continuar resistindo, mesmo sem a família, procuram nos amigos que fazem na rua substituições que 
compensem a falta de afeto, como aparece nesta observação do A.N.D.: "Minha família são os companheiros de rua. São tri comigo e faço tudo pra ser legal com eles. A gente conversa, brinca, se diverte". Se entendermos família não como núcleo isolado, mas como uma das instituições contraditórias que reflete em seu bojo a sociedade patriarcal e as necessidades de reprodução de mão-de-obra barata para o capital, construiremos uma posição teórica que ultrapassa a atitude ingênua de culpar esta família, para chegar à atitude crítica do entendimento desta realidade como uma totalidade cujas partes encontram-se intimamente articuladas, determinando-se mutuamente.

Compreende-se, então, desse ponto de vista teórico, que, quando os meninos rejeitam a familia, rejeitam, de fato, um modelo "determinado" de família, que não mais corresponde à realidade. Isto está implícito na fala de AND., já citada anteriormente, onde, ao mesmo tempo que demonstra afeto e compreensão das atitudes da avó, conclui que não é possível seguir seus conselhos: "Ela me dá conselhos pra não usá mais drogas, pra começa a trabalha, mas eu não consigo atender o conselho dela."

Há, ainda, o sentimento de culpa, revelado por alguns, por não conviverem mais com o grupo familiar. Ouçamos A.L.B.: "Então eu tenho este remorso, então não consigo fica em casa, né dona, por isso!" Para entender esta afirmação, precisamos relacioná-la com sua descrição anterior sobre como era a vida em família: "Bom, a gente levava a vida devagarzinho, era meio chata. É que às veis faltava coisa. Eu tinha que luta muito, trabalha demais." Somam-se a estas reflexões, as demais acerca da violência familiar. Não é dificil compreender que há lógica quando os meninos e as meninas, apesar do desejo de estar junto aos seus, pelas condições reais desta convivência, acabam procurando, em outros espaços, em geral na rua, mehores condições de sobrevivência. Acrescente-se a isso que a rejeição ao modelo autoritário e contraditório da família não se dá apenas nas classes mais empobrecidas; vale o mesmo para a violência ou abusos de todo tipo que são comuns às diversas classes. Sabe-se, hoje, que violência, abuso sexual e abandono são comuns à classe social mais elevada. $\mathrm{O}$ que faz com que pareça haver maior incidência entre os mais 
pobres é a forma discriminatória e desrespeitosa como estas famílias vêm sendo tratadas ao longo da história de exploração e empobrecimento crescente a que vêm sendo submetidas. É aviltante, por um lado, o tipo de ingerência da maioria das entidades ditas promotoras de "Bem-Estar" (juizados, FEBEMs, algumas entidades religiosas e leigas, polícia) junto aos meninos e às meninas de rua e, por outro lado, a ação dos meios de comunicação social com suas manchetes sensacionalistas e tendenciosas. Mesmo com a garantia constitucional de inviolabilidade do direito à privacidade e proteção da família, à criança e ao adolescente em especial, ainda presenciamos espancamentos, invasão policial armada nas favelas, muitas vezes sem nenhuma autorização judicial (exemplos disso são vários incidentes presenciados e vividos por educadores na vila Tronco e nas ruas centrais de Porto Alegre) ou, simplesmente, o recolhimento de meninos e meninas à Divisão Para Menores (DIPAME-Polícia Civil) e à FEBEM.

Relacionada, ainda, à família está a questão trabalho-salário. A maioria dos meninos está nas ruas para ganhar dinheiro para si e para o grupo familiar, alguns poucos atuando no mercado formal (minoria), a maioria em biscates e mercado informal como vendedores, engraxates, limpadores e guardadores de carro, entre outros. Alguns meninos preferem o ganho informal, pois dizem ganhar mais, não possuem horários para cumprir, patrões para obedecer. Isso está explícito na afirmação de J.V., 17 anos: "O que eu gostava de ter?! Uma casa minha, uma loja minha, trabalha pra mim - que nunca gostei de trabalha prós outros. Por causa que se a gente tá doente e um dia a gente perde aquele dia, se a gente não pode ir naquele dia, e assim a gente nunca consegue nada." Embora sua fala pareça esgotar-se numa atividade individualista, detectamos, no resto do depoimento, elementos mais significativos que denotam uma crítica ao trabalho formal e às relações decorrentes do mesmo, como na constatação de que trabalhar para os outros nao leva a nada. Está contida, aí, a negação da relação comum entre capital e trabalho, em que até o direito a faltas justificadas, garantidas pela legislação trabalhista, lhes é negado. Sabemos, por outras fontes, do controle do número de atestados médicos, do não pagamento do salário integral (consta na carteira um 
salário e recebem outro), de demissões quando um empregado não consegue (mesmo que por doença, à vezes causada pela própria atividade) integrar-se ao ritmo de produção desejada. Destacamos, ainda, a ênfase no: "assim a gente nunca consegue nada" que é a certeza de que trabalhar para o outro não proporciona condições de emancipação, de usufruto, de ser.

Há também, forte sentimento de ambivalência por parte dos meninos e das meninas, o que, no entanto, não desqualifica suas reflexões, críticas e seus posicionamentos feitos em outros momentos. Como exemplo, J.A.V., mesmo ao criticar o trabalho para os outros, em certa ocasião deu este depoimento: "Eu gostaria de trabalhar numa agência, assim, de fazer lá esses negócios... Senão, vou sê fiscal de obra Por causa que, desde pequeno, eu quis ser. Achava um negócio interessante, conhecer todo este tipo de coisa e fiscal de obras ganha muito dinheiro." Percebese que, embora se contradiga com relação a trabalhar em uma agência ou como fiscal de obras, o que significa trabalhar para os outros e não para si, como em outro momento mencionava, há coerência quando explica que o fiscal tem algumas vantagens como: conhecer muitas coisas e ganhar mais dinheiro.

Outro aspecto importante a ressaltar, tanto no trabalho forma! como informal, é a possibilidade, mesmo que mínima, do usufruto de bens. Diz J.A.V.: "Tem gente que consegue, mas tem que trabalha muito, para ter uma casinha de material. Trabalha um ano pra tê uma casinha, mais um ano pra tê um carro, mais um ano pra compra mais alguma coisa. Eu sempre quis ter uma bicicleta, de papel (com nota fiscal), minha mesmo, anda com roupa bonita, anda limpinho, com dinheiro no bolso. Nada que é dos outros, nada robado...". Acrescenta F.U.N., falando sobre como usa o dinheiro que ganha: "Gasto, compro refri, compro mortadela, jogo fliperama ..." Continua J.M.: "Compro roupas, calçados, essas coisas". Destacamos, dessas falas, a consciência do tempo de trabalho gasto para que se possa adquirir algum bem e, ainda, o fato de perceberem que só alguns conseguem, em especial, os bens mais sofisticados e duráveis, como casa, automóvel. E o desejo forte de possuir algo de seu como a bicicleta, ter roupas bonitas e, sobretudo, não ser constrangido a toda hora sobre a 
legalidade da posse ("ter o papel"). A preocupação com o "papel" devese ao fato de que, quando aparecem com roupas novas ou algum objeto, mesmo que tenham adquirido pelo trabalho, são constrangidos pela polícia a comprovarem que é fruto de roubo - tratamento discriminatório e preconceituoso a que são, não raras vezes, submetidos.

Já ouvimos de muitos meninos e muitas meninas a alegação, ao se referirem a essa situação, de que tanto faz trabalhar ou "roubar", uma vez que com o trabalho é dificil adquirir algo e, ainda, quando o conseguem, são tratados como ladrões. Nesta linha de reflexão, acabam concluindo, muitas vezes, que "roubar" é mais vantajoso. Acrescente-se a isso que a maioria dos meninos considera o roubo, a prostituição e a mendicância como trabalho e de certa forma, em muitos aspectos, são "trabalhos" que lhes possibilitam maiores vantagens, inclusive de usufruto no sentido de, não raras vezes, ganhar mais nesse tipo de trabalho do que em outros considerados legais e de acordo com as regras "morais" da sociedade. Afirma Galeano (1991) que "o delito é para os meninos a única maneira de praticarem a propriedade privada". Essa reflexão, indubitavelmente verdadeira, exige muita coragem para ser dita, pois convivemos com a incoerência e a hipocrisia de uma sociedade que, como o próprio autor diz: "adora as coisas e despreza as pessoas". Uma sociedade que sabe punir, como ninguém, em especial a classe trabalhadora quando esta ousa querer, também para si, alguns dos bens que, a todo momento, são exibidos pela mídia. E, o que é mais sério, passando a idéia de que ter é garantia de felicidade, de ser. Na realidade, o "ter" — condição necessária mas não suficiente do ser - é garantido apenas para uma minoria, sobrando, para a grande maioria, o trabalho pesado, a sub-habitação, o desemprego e, para uma minoria crescente, a rua como alternativa de sobrevivência, ou seja, como negação do ser.

Problemática é a relação dos meninos e das meninas com as instituições da sociedade civil com a qual contracenam e se confrontam. Contradizendo alguns sentimentos de conformismo, acima referidos, aparecem sentimentos de perplexidade diante da realidade social, como expressa L.U.N., num encontro de meninos em Porto Alegre, em que houve um momento muito forte de denúncia por parte dos meninos em 
relação à operação "Papai Noel", também, já referida: "Tia, eu só quero que a senhora me explique, como é que eu, que vivo sempre na rua, não posso passar o Natal na rua, tenho que ser preso. E os outros que têm casa, tem tudo, podem ficar na rua, numa boa? Me explica, tia, me explica que eu quero entender". É um momento rico de reflexão, de tomada de consciência de que algo não está certo, que há, no mínimo, incoerência na forma de proceder da sociedade. A classificação da polícia como a instituição mais violenta, apesar de não ser a única, constituiu, também, uma tomada de consciência marcante. A violência policial é praticamente a única que os meninos e as meninas não perdoam. Um deles nos interpelava, certa ocasião, a respeito do dístico: "Vamos viver sem violência", inscrito nas portas dos carros da Brigada Militar. O menino perguntava ironicamente: "Por que escrever aquilo se eles são os pior? Os que mais são violentos?"

Com relação a policiais, as denúncias são inúmeras: de prisão sem motivo, falsas acusações de roubo, apreensão do produto roubado - do qual se apropriam os PMs, segundo outras informações - criando-se assim um círculo vicioso: roubo, prisão, extorsão, roubo... Alegam ainda que a prisão, na maioria das vezes, é acompanhada de tapas, "cascudos" e tratamento pejorativo como "ladrões", "trombadinhas"... Essas agressões, como já citamos algumas vezes, foram realizadas em nossa presença e, em alguns momentos, era dirigida a nós, educadores. Existe, inclusive, na Ordem dos Advogados do Brasil (OAB), um processo encaminhado em 1989, como alternativa encontrada para apurar fatos como esses; desse processo, até hoje não se tem notícias. Muitas denúncias desse tipo (a maioria entregue em audiências públicas, com divulgação na imprensa), encaminhadas à Secretaria de Segurança Pública de Porto Alegre, de 1987 a 1992, não tiveram resposta. Denúncias que se referem à violência policial em plena vigência do Estatuto da Criança e do Adolescente, o que mostra o desrespeito aos direitos conquistados nesta lei, como os próprios meninos relatam: "Nos obrigaram a ir para a parede e a deitar no chão. Em seguida, nos revistaram e começaram a chutar nossas pernas e foram chamando um por um... e agredindo a socos, cacetadas e pontapés. Os soldados diziam pra se ajoelha e pedi perdão... 
nos jogaram o livro do Estatuto na nossa cara e mandaram cada um prum lado... e diziam: pode ir ao juiz procurar teus direitos... Menores que andam no centro são agredidos por brigadianos que abusam da lei..." Esse relato foi feito por um dos meninos por escrito e denota o abuso de poder e, conseqüentemente, o descumprimento da lei, por parte daqueles que são os que, em tese, deveriam cumpri-la. Esse relato de A.L.B. nos dá conta do grau de consciência que ele possui: primeiro, por conhecer seus direitos (na noite da agressão ele andava, inclusive, com o Estatuto na mão); segundo, por trazer essa agressão para a denúncia pública e, por fim, pela capacidade de relatar e criticar um ato do qual foi protagonista.

Alguns dias após esta ocorrência, sem que nada houvesse mudado, novamente alguns meninos participaram de uma das reuniões da Comissão Local do MNMMR, trazendo novas denúncias, segundo as quais não podiam sentar na praça ou trabalhar nesse local, sendo obrigados pela PM a perambular por locais afastados do Centro. Era grande, nessa ocasião, a revolta dos meninos, que se diziam humilhados perante a sociedade. "E a nossa cara perante a sociedade, como fica?" AJO. dizia: "Isso é constrangimento da lei." Percebe-se, claramente, a consciência do direito adquirido enquanto cidadãos e o fato de procurarem o MNMMR ao qual se filiam, espontaneamente, para, de forma mais ampla, reivindicarem o cumprimento da lei.

Salientando o esforço crítico dos meninos e das meninas de rua, emerge a consciência da divisão da sociedade em classes, identificadas pela afirmação da existência de ricos e pobres. Há meninos que caracterizam os ricos, primeiro, pela origem da riqueza: há os que são ricos por herança; os que são ricos porque são espertos (em especial na sua relação com o pobre); os que são ricos porque Deus quer e, por fim, há uma categoria de ricos (rara) que ficaram ricos pelo estudo e pelo trabalho. Esta última categoria é, até, justificada pelos meninos e pelas meninas como uma forma permitida de riqueza. Isto aparece em alguns depoimentos que, ao denominarem o rico de "burguês", afirmavam que burguês que não era explorador era o que tinha se tomado rico pelo trabalho. Identificam a classe dos ricos ou burgueses pelos bens que possuem e usufruem: "Ricos são finíssimos, têm casa de três andares, possuem carro, vão para onde querem, compram tudo de bom..." 
Identificam o pobre de uma única maneira: é aquele que não possui. Por que os pobres não possuem? Por não serem espertos, são esquecidos por Deus, não receberam herança ou, ainda, por culpa do governo. "Pobre come mal, não possui casa, luz, água, ... pobre não tem condição de pagar..."

Embora saibam da existência das classes, caracterizam-nas e tentam explicá-las, a maioria atribuindo a Deus um papel fundamental na "sorte" de os indivíduos serem ricos ou pobres - além da condição de ser esperto, ganhar herança ou, até, pelo trabalho. É o nível da consciência ingênua ou, no máximo, semi-intransitiva, de que fala Paulo Freire (1980, p.26): "Num primeiro momento, a realidade não se dá aos homens como objeto congnocível por sua consciência crítica. Noutros termos, na aproximação espontânea que o homem faz do mundo, a posição normal, fundamental, não é uma posição crítica, mas ingênua. Esta tomada consciência não é ainda a conscientização, porque esta consiste no desenvolvimento crítico da tomada de consciência".

A definição de classe social dos meninos também nos chama a atenção, pois, a classe burguesa, no entendimento deles, é fracionada: há quatro tipos de ricos, enquanto pobre é um só. O rico não é identificado como aquele que detém os meios de produção, e, sim, como aqueles que pode usufruir de casas, roupas, comida, lazer. A maioria descreve a realidade como ela se manifesta na aparência, sem entender suas causas, o que existe atrás desta aparência.

Este texto por si só não dá conta da profundidade dos depoimentos dos meninos e das meninas, mas delineia a alguns aspectos que julgamos importante analisar. Os temas dos demais companheiros de pesquisa certamente abordam com pertinência questões específicas de suas áreas de saber, o que qualifica nosso trabalho. Quanto a nós, esperamos, pelo menos, contribuir para mudar a imagem que a sociedade ainda tem das crianças; contribuir através, não só de nossa postura político-pedagógica, mas, principalmente, confrontando este imaginário da população com a argumentação dos próprios sujeitos, o que revela, não mais a criança abstrata, discriminada e estereotipada, mas o ser concreto, cidadão-criança, nem perfeito, nem imperfeito, mas pessoas em desenvolvimento, com seu saber, sua ambivalência e, sobretudo, com sua humanidade. 
Para concluir, fazemos nossas as palavras de José de Souza Martins (1991):

Gostaríamos, igualmente, que este nosso trabalho encorajasse os pesquisadores das ciências sociais a trabalharem mais amplamente com a concepção de que os mudos da História, os deserdados, banidos e excluídos, os sucateados pelas conveniências do poder e do capital, são cada vez mais sujeitos do processo histórico. Reconhecendo que há neles uma rica inteligência dos processos e situações em que estão envolvidos. Nesse caso, particularmente, esses sujeitos são crianças, que dão significativa demonstração de compreensão do que estão vivendo. As ciências sociais dariam um passo importante no seu desenvolvimento se reconhecessem que são elas, nos dias de hoje, os principais portadores da crítica social. E que já não são elas o instrumento dessa crítica, como foram no passado. Quando se fala numa crise da sociologia, convém ter em mente que grande parte dessa crise decorre do rompimento das relações entre os cientistas sociais e aqueles grupos e classes da população que, por sua situação social de excluídos, ganham uma perspectiva crítica, rica e penetrante em relação ao estado em que a sociedade se encontra. Mesmo que essa visão sofra as reconhecidas deformações de uma alienação que oculta aspectos fundamentais da realidade social Mas esse é, certamente, ponto de partida mais rico e questionador do que os compromisso e perspectivas que têm bloqueado o pensamento sociológico.

\section{A lógica subjacente à fala dos meninos e das meninas de rua}

A análise que aqui fazemos de fala dos meninos e das meninas de rua orienta-se por categorias retiradas de epistemologia genética piagetiana, em especial do tratado de Piaget (Piaget et al., 1977) sobre a abstração reflexionante e da lógica formal. Essas categorias estendem-se das narrativas de ações na seqüência em que ocorreram - a mais simples seria a narrativa, enquanto ocorre a ação, o que não é o caso, aqui — até o raciocínio hipotético-dedutivo e a argumentação concatenada. A finalidade prática dessa análise é a de indicar aos possíveis educadores desses meninos e dessas meninas o teor instrumental da lógica desses sujeitos, como requisito mínimo para dar prosseguimento ao seu processo 
de alfabetização e à seqüência normal da educação escolar posterior. Sua finalidade teórica é a de descobrir se crianças afetadas tão frontalmente pelos mecanismos perversos de marginalização social, atuantes em nosso meio, são incapazes, como freqüentemente se afirma, de uma atividade mental mínima necessária para enfrentar o processo normal de escolarização.

Para entender o ato significador de nossa análise, fazemos uma breve exposição da teoria de abstração reflexionante de Piaget (Piaget et al., 1977).

O processo de abstração reflexionante comporta sempre dois aspectos inseparáveis: de um lado, o reflexionamento (réfléchissement), isto é, a projeção sobre um patamar superior daquilo que foi tirado do patamar inferior, como acontece com a passagem da ação sensório-motora à representação; ou da assimilação simbólica pré-operatória à operação concreta, etc. De outro lado, uma reflexão (reflexión), "como ato mental da reconstrução e reorganização sobre o patamar superior daquilo que foi assim transferido do inferior" (Becker, 1993, p.303).

De onde vem o "material" retirado por reflexionamento? Vem de duas fontes possíveis: a) dos observáveis, isto é, "dos objetos ou das ações do sujeito em suas características materiais". O mecanismo que assim procede leva o nome de abstração "empírica"; b) dos nãoobserváveis, isto é, das coordenações das ações do sujeito, coordenações endógenas (ouço, observo uma criança de dois anos chamando um cavalo de "au-au", mas não ouço, não vejo, não observo a coordenação que a levou a generalizar para o cavalo o nome que atribuía usualmente ao cachorro); Piaget chama de reflexionante (réfléchissante) a esta forma de abstração.

A abstração reflexionante tem dois desdobramentos: a) se o objeto "é modificado pelas ações do sujeito e enriquecido de propriedades tiradas de suas coordenações" (Becker, 1993, p.303), como acontece quando uma criança de 3 anos enfileira, sem plano prévio, alguns objetos e, somente então, o constitui como totalidade, constituindo, portanto, um significado; temos, então, uma abstração pseudo-empírica (pseudo-empirique). É 
pseudo-empirica porque aquilo que a criança retirou não esta no objeto, isto é, no observável, mas nas relações entre os objetos (carrinhos), isto é, no que é não-observável; em outras palavras, a criança retirou dos objetos o que ela colocou neles e não o que lhes é próprio; e o que ela colocou neles é produto da coordenação de suas ações que fez dos objetos, inicialmente isolados, um conjunto; por isso, tal abstração faz parte da categoria "reflexionante" e não da categoria "empírica"; b) se o resultado de uma abstração reflexionante, de qualquer nível, tornar-se consciente, temos uma abstração refletida (réflechie); isto acontece, por exemplo, quando uma criança operatório-concreta se apropria de elementos comuns às operações de adição de unidades, dezenas e centenas.

O que significa abstração? A palavra latina abs-trahere significa "retirar", "arrancar", "extrair" algo de algo. Nunca a totalidade, mas apenas algo, algumas características.

O que o sujeito retira por abstração? Aquilo que ele pode retirar, isto é, aquilo que seu esquema de assimilação atual possibilita que ele retire. A abstração está limitada pelo esquema de assimilação disponível no momento; o esquema disponível é síntese das experiências anteriores, isto é, das abstrações, empíricas e reflexionantes, passadas; mas ele pode modificar este esquema. Ele o modifica por acomodação. Assim que um esquema de assimilação é percebido como insuficiente, para dar conta dos desafios no plano das transformações do real, o sujeito volta-se para si mesmo produzindo transformações nos esquema que não funcionaram a contento. $\mathrm{O}$ esquema assim refeito pode proceder, agora, a novas assimilações ou retiradas (abstrações) de características dos objetos, das ações e das coordenações das ações; isto é, pode proceder a abstrações empíricas ou reflexionantes.

A abstração reflexionante dá-se sempre por dois processos complementares: a) de uma lado o reflexionamento, que consiste na projeção sobre um patamar superior daquilo que foi retirado de um patamar inferior, como se fosse um refletor. Tal acontece quando a criança, já possuindo a capacidade simbólica, traz ao plano da representação o que até agora vigorava somente no plano da coordenação das ações sensório- 
motoras; b) de outro lado, a reflexão, que consiste num "ato mental de reconstrução e reorganização sobre o patamar superior daquilo que foi assim transferido do inferior" (Becker, 1993, p.303). Para ficar no exemplo, aquilo que é trazido do plano das ações ou da coordenação das ações sensório-motoras é reconstruído e reorganizado, em nível endógeno, no plano da representação. Mesmo que numerosas crianças manuseassem um mesmo objeto, ainda assim não teríamos duas compreensões exatamente iguais desse objeto, pois o mundo desse segundo patamar, mundo endógeno das coordenações das ações, é diferente de uma para outra criança, pois ele depende da experiência anterior ou da história das ações dos indivíduos. Mas, e isso é fascinante no ser humano, não importa o caminho percorrido pela experiência ou pela história das ações de um indivíduo, ele poderá chegar ao conhecimento universal e necessário. Podemos imaginar experiências tão diferenciadas em função da geografia, da cultura, da língua, etc, como as dos esquimós, dos alemães, dos negros bauleses da Costa do Marfim, dos gaúchos, dos nativos de ilhas do Pacífico, dos índios brasileiros, dos meninos de rua provindos de realidades diferentes... Todos os sujeitos dessas experiências podem chegar ao conhecimento universal e necessário, não importa a diversidade de sua experiência, isto é, de suas ações e de suas abstrações - empíricas ou relfexionantes. Nisso todos eles se igualam constituindo o sujeito epistêmico, o sujeito do conhecimento. Nada, no entanto, garante apriori que eles cheguem atai ponto. $£$ somente a ação, entendida como abstração reflexionante, garante a posteriori a chegada a este patamar de conhecimento. Mas - e isto é o que fascina no conhecimento humano! - , uma vez chegado a esse patamar operatório-formal, a diversidade de experiências é superada sem precisar ser anulada, sem sumprimir a diversidade, basta superar as diferenças de linguagem, para que representantes de culturas tão diferentes possam comunicar-se.

Privilegiaremos, intensamente, nesta análise, a fala desses meninos e dessas meninas, a fim de possibilitar ao leitor outras análises possíveis, pelo menos tão úteis quanto a nossa. Transitaremos por categorias dispostas em tal ordem que nos revelem níveis crescentes de complexidade de pensamento, ou melhor, de condições apriori de conhecimento. 


\section{A) NARRATIVA DE AÇÕES}

À solicitação do entrevistador para falar sobre as "batidas" da polícia, A.J.O. diz:

Tem vezes que a gente tem um flagrante em cima, né? E eles, meio desconfiados, chegam, tiram o flagrante e levam pra FEBEM. A gente tá bem belo, não tem flagrante nenhum, eles vêm querer dar ataques, querem dar na gente; a gente não podendo resistir à dor e nem reagir contra eles; afinal de contas, eles tão com cacetete e com canhão na mão.

Apesar de explorarmos, aqui, a narrativa de ações, na ordem em que se sucederam, encontramos algo mais complexo: um raciocinio implícito: "eles" têm todo poder porque "têm cacetete e canhão na mão".

A.F.E., 16 anos, prossegue na mesma direção, narrando ações:

Nós tinha vindo do som, nós tava subindo a lomba, ali onde pego o ônibus para Sapucaia; dai os brigadianos pararam e botaram nós no chão e começaram a chutar, perguntaram se nós não tinha nada. Daí largaram nós. Assim nunca mais, quando eles pegaram nós assim eles dão uns tapas, cascudos. Eles dão mesmo! Daí soltaram, daí nunca me pegaram assim.

J.A.V., 17 anos narra:

Eu não podia andar descansado que eles me viam, me levavam preso e nie cagavam de pau, tanto os brigadianos como os do juizado. Nao podia ficar quieto no meu canto, tinha que tá sempre me escondendo; era por isso que eu roubava. Quando eu tava quieto trabalhando eles iam ali, pegavam a gente e cagavam a gente de pau, até a gente dar alguma coisa. E a gente apanhando, ali, não tem aquele que não dê nada; nem que seja uma "cebola" (relógio de má qualidade) a gente dá pra eles. Não tem aquele que dê nada; não dá nada, eles matam o cara como já mataram vários.

S.A.N., 14 anos, falando da violência, narra ações que, até certo ponto, generaliza como próprias de policiais:

Te dão pau em ti, te chutam pra cima, te tiram a roupa, teu tênis, o que tem em cima. 
I.T.A, 13 anos, denuncia a injustiça da violência que ela e sua companheira sofreram:

A última vez que foi tava eu, a L.S., brigando lá na Praça Quinze. Daí chegou duas mulher brigadiana e agarraram nós e botaram as algemas nos meus dedos e nos da L.S.. Aí levaram nós lá pra aquela... da Praça Quinze que tinha lá, subiram lá, deram em nós... porque tinha fincado as unhas na brigadiana. Aí começaram dá em nós e levaram nós pra FEBEM só porque nós tava brigando.

V. AR., 16 anos, narra várias ações, no decorrer da entrevista sobre pescaria, por exemplo:

O cara levanta cedo, procura minhoca pra ir pro rio e fica a noite inteira.

Temos, aqui, da parte dos vários sujeitos, sempre narrativas de ações individuais ou coletivas. Narrativas que se caracterizam por seriar as ações na seqüência em que elas ocorreram: na ordem temporal (contingente), e não na ordem operatória (necessária). A ordem temporal dá-se pelo respeito à seqüência das imagens obtidas por abstração empírica, a partir do espaço vivido - trabalho de percepção. Daí, sua característica estática. O pensamento, em nível operatório, ao contrário, desvincula-se das gesíalten perceptivas, estruturando-se por totalidades formais que não se submetem a um espaço e a uma seqüência temporal. Esta seqüência pode estar mais ou menos "colada" ao espaço objetivo em que se desenrolaram as ações. O espaço objetivo pode ser substituído por um espaço mais representativo; nesse caso, a seqüência liberta-se da cronologia original, tomando-se mais versátil - o que equivale a um aumento na qualidade do pensamento. Se compararmos M.O.L., veremos que a qualidade das coordenações temporais de N.O.D. é muito superior às deM.O.L.

\section{B) DESLOCAMENTONOESPAÇO}

AJO., 15 anos, diz:

Desde os meus 7 anos, até os meus 12 anos, eu morei no Sarandi; que era a época que eu estudava, morava na Maisonave, uma instituição particular. E 
nessa de eu ter que se mudar aqui pra Tristeza, sair lá de Sarandi pra Tristeza, perdi muitos amigos que estudavam comigo.

Nem todas as coordenações espaciais são da mesma qualidade. Há seqüências espaciais, nessas narrativas, marcadas fortemente pelo aspecto figurativo, isto é, fixadas como uma seqüência de fotografias de cada espaço por onde ocorreram os deslocamentos. Há, no entanto, seqüências espaciais, coordenadas num nível muito próximo da reversibilidade operatória: o sujeito que narra a seqüência poderia narrar de trás para a frente, reconhecendo, nessa ordem inversa, a seqüência de deslocamentos da ordem direta. Predominam, nessas narrativas, pareceme, coordenações espaciais fortemente operatórias - em nível concreto, principalmente.

\section{C) O CONTROLE DO TEMPO}

O desembaraço com que os meninos e as meninas falam dos dias da semana, do término da greve, da idade das pessoas, etc. mostra o quanto a construção da noção de tempo foi efetivada. Relativamente restrita é a generalização dessa noção. Perguntaríamos, como eles representariam um alargamento do tempo histórico - da história regional, nacional ou mundial, se isso lhes for solicitado. Com certeza, o ponto de partida já está assegurado; a generalização é, porém, precária, como veremos.

Diz J.O.R., respondendo à entrevistadora: "Não sei, só sei que a minha aula volta só quando terminar as greves". Sôbre o encontro marcado para a entrevista em que a entrevistadora não compareceu, diz: "Não, eu fiquei chateado com a Letícia. Ela assim falou: sexta-feira eu venho aqui, eu e tal não sei quem, aí nós vamos lá na tua casa... e aí eu esperei, esperei até às 4 horas da tarde e ela não apareceu e às 7 horas eu fui embora". Segue-se um bate-boca entre entrevistadora/pesquisadora e entrevistado sobre a data marcada para o encontro:

$$
\begin{aligned}
& \text { R:- Sexta? } \\
& \text { J.O.R.: }- \text { E. }
\end{aligned}
$$


P.: - Nao foi sábado?

J.O.R.: - Não, foi sexta. Choveu toda a manhã e de tarde ficou meio assim, aí a gente veio igual, mas já achando que vocês não tavam aqui.

R: - Sexta-feira me parece que não choveu... Por que tu marcaste sexta e não sábado?

J.O.R.: - Porque sábado... eu não venho.

P.: - O que tu ficas fazendo sábado?

J.O.R.: - Sábado eu tenho muita coisa para fazer.

F.E.R., 13 aos, diferencia os dias da semana e controla o tempo pelo relógio:

P: - Como é que tu fazes para jogar com os amigos da Vila se tu trabalhas toda a semana, aqui?

F.E.R.: - Não! Jogo sábado e domingo...

P: - Sábado e domingo?

F.E.R.: - É, e aqui às três, quatro hora dá pra jogar até às cinco, seis e meia, seis hora.

A.J.O., 13 anos, é claro no controle do tempo vivido:

P: - Quanto tempo tu morastes em São Leopoldo?

A.J.O.: - Cinco anos. P: - Quantos anos faz que tu vieste pra cá? A.J.O.: — Faz seis anos.

V.A.R., 14 anos, falando sobre pescaria, diferencia "durante a semana" de "fim de semana", "manhã cedo" de "noite"; na diferenciação de "verão" e "não verão" já não é muito claro:

P: - Vocês fazem isso todos os dias?

V.A.R.: - Não, só nos fins de semana. Agora não dá.

P: - Por que não dá?

V. A.R.:- Dá mais no verão.

P: - Tem alguma história que no verão dá mais peixe que no inverno?

V.A.R. -Não sei.

P: - Você se encontram só de noite... saem de manhã cedo?

V.A.R.: - Saem de manhã cedo, chegam no fim de semana, fazem um rancho, comida para comer. 
Sobre sua passagem pela FEBEM, é contraditório, pelo menos aparentemente, ao tratar do tempo: Chama "um mês e meio" de "tempão", diz não lembrar deste tempo:

P.:-Lá naFEBEM você apanha. E ficando na rua, você apanha, também? V.A.R.:- Apanha de vez em quando. Fica preso lá, sai pra rua de dez em dez dias. É mais ou menos. A gente vai num cinema, vai num som. Tem guria, tem sala, tem guria pra gente; se a gente que ir num circo eles levam, dão roupa limpa, perfume, tudo.

R:- Que idade tu tinhas quando foste pra lá?

V.A.R.:- 12 anos.

R:- Quanto tempo faz?

V.A.R.:- Faz um tempão, um mês e meio, acho.

$\mathrm{R}$ :- Lembras a época em que tu foste pra lá?

V.A.R:- -Não.

Pode-se sugerir, aqui, a hipótese do quanto a estruturação lógica do tempo está presa aos estados afetivos do indivíduo. Pode-se pensar, com Heidegger, a distinção entre tempo cronológico (cronômetro: um mês e meio) e tempo Kairológico (existencial, vivido, "um tempão").

A "qualidade" do tempo varia do tempo próximo, vivido, ao tempo resultante de múltiplas coordenações. Do tempo imediato, às coordenações do tempo mediato: o tempo operatório. A.J.O. e N.O.D., parece-me, aproximam-se mais de coordenações temporais operatório-formais, enquanto os demais procedem a coordenações operatório-concretas e, não raramente, intuitivas. É importante salientar que nenhum dos sujeitos citados mostra dificuldades maiores de coordenar o tempo vivido. Esta coordenação é condição apriori de um processo educacional formal.

\section{D)FRAGMENTOS XTOTALIDADE}

Não há argumento sem totalidade constituída ao nível simbólico - totalidade operatória, não apenas figurativa (gestáltica). As argumentações dos meninos e das meninas entrevistados aproximam-se mais ora de uma totalidade gestáltica (aspecto figurativo do pensamento), 
ora mais de uma totalidade operatória (aspecto operativo do pensamento). É freqüente a totalidade compor-se, no plano da consciência operatória, portanto, aos poucos, mediante numerosas perguntas do pesquisador. Esta ocorrência parece combinar com um precário nível de consciência. Acompanhemos as respostas de C.A.L., 14 anos:

R:-C.A.L., tu já lcvastc alguma batida da polícia?

C.A.L.:-Ummonte.

P. - De quem tu levaste batida?

C.A.L.: - Dos brigadianos.

P.:- Só dos brigadianos?

C.A.L.: - Ah! dos caras do JM (Juizado de Menores), da civil.

"Os brigadianos, mais os caras do JM e da civil" constituem uma totalidade bem mais operatória do que "um monte", que está bem mais próximo de uma gestalt perceptiva.

FER., 13 anos, embora utilizando a forma básica do argumento logicamente aceitável: "Eu parei de estudar porque a professora era muito xarope", o faz num plano de conteúdo muito elementar:

P: - Por que tu paraste?

F.E.R.: - Porque a professora era muito xarope.

$\mathrm{R}:-$ Xarope $\mathrm{cm}$ que sentido, o que ela fazia para ser xarope?

F.E.R.: - Ah, bobaiona. Começava a xingar o cara c eu xingava ela também, daí deu, fui expulso.

Mas, de qualquer maneira, F.E.R. consegue recuperar ações práticas, no sentido da constituição de um conceito mais elaborado, abstrato: a violência.

P: - Enlâo, vamos falar sôbre violência. O que é violência pra ti?

F.E.R.: - Ah, violência c quando a gente lá engraxando, aqui. Vai embora com o dinheiro, vem passa o talco no cara, dá na gente, briga.

P: - Passar o quê, o talco?

FER.: - Toma o dinheiro da gente, briga com a gente.

V.A.R., 14 anos, embora recupere ações práticas, compondo a totalidade "pescar", o faz de forma marcadamente figurativa. O que tem a ver a ação de levantar cedo com pescar? Ficar a noite inteira no rio? 
R: - Como é pescar? Nunca participei de uma pescaria.

V. A.R.: - O cara levanta cedo, procura minhoca pra ir pro rio e fica a noite inteira.

$\mathrm{R}:-\mathrm{Tu}$ vais sozinho ou em grupo?

V.A.R.: - Não, eu vou com um monte de homem.

R: - Que homens são?

V.A.R.: - Meus cunhados e outros, meus amigos.

R:- Que moram na Vila?

V.A.R.: - Sim, da Alô Perdido.

V.A.R.: - Claro, botando o caiaque pra dentro do rio, botando a rede. Aí quando chega de manhã, tira a rede.

\section{E) AFIRMAÇÃO SEGUIDA DE CONJUNÇÃO ADVERSATIVA}

A qualidade da afirmação seguida de conjunção adversativa é, certamente, superior à afirmação dominada pelo quadro perceptivo. Quando o pensamento torna-se capaz de introduzir modificações, desvios de rota, no desfilar das imagens obtidas por abstração empírica que determinam a narrativa, podemos dizer que houve um salto qualitativo. Vamos explorar, aqui, o uso das conjunções adversativas — especialmente do "mas" — nos depoimentos dos nossos sujeitos.

AJO., 15 anos, diz:

Eu não gosto de perder amigo nenhum. Ele pode ser até xarope, pode às vezes me encher o saco, mas eu não gosto de perder a amizade dele; a amizade eu não gosto de perder. Eu posso perder tudo as outras coisa, mas a amizade não. Eu tenho um sentimento forte peia amizade que quando eu perdo me fere. Me deixa sozinho, eu fico pensando porquê, sem resposta; mas um dia eu vou encontrar ela. Eu vou encontrar porque ela é minha amiga. Eu e ela - gostamos muito eu e ela - , nada com namoro, mas amizade forte mesmo. Eu não quero perder ela... Um dia nós vamos nos separar e um dia nós vamos nos encontrar, correndo um pro outro, de tanta saudade, às vêzes até caindo lágrimas, mas lágrimas com um sorriso, lágrimas de emoção, lágrimas de ver alguém que a gente ficou tanto tempo longe dele, e tu sempre procurando.

Por que afirmamos a superior qualidade do pensamento quando se usa a conjunção adversativa? Resumamos AJO: "Eu senti o desgosto 
de perder um amigo (fato real), mas a amizade eu não gosto de perder (construção representativa)." "Eu a perdi (fato real), mas um dia vou reencontrá-la (construção representativa)." "Lágrimas de saudade (sinal de tristeza), mas lágrimas com sorriso, com emoção (construção representativa)." A conjunção adversativa consiste num acréscimo que a atividade do pensamento impõe à descrição puramente perceptiva. O uso da conjunção adversativa traz algo novo, obtido por abstração reflexionante, que escapa do determinismo da abstração empírica. É neste sentido que afirmamos que o uso da conjunção adversativa faz crescer o pensamento em qualidade.

A EE., 16 anos, ao responder à pergunta de como poderia ir melhor na escola, afirma: "Acho que podia até ser melhor, mas não tenho essa chance."

A.V.U., 14 anos, à pergunta: "Tu gostas de vestir a roupa da moda?", responde: "Gosto tia, mas não tenho dinheiro pra comprar."

V.A.R., 14 anos, perguntando se, em caso de roubo, a polícia pode bater nele, responde: "Se eu robô, eles têm o direito de bater em mim." Pergunta-se então: Por quê? Responde: "Claro, eu tava robando, mas se eu não tou roubando eles não têm o direito de bater em mim, porque eu não tô fazendo nada." Este depoimento contém, sob o ponto de vista lógico, muito mais que o uso do conectivo "mas". Contém um argumento quase silogístico e um raciocínio hipotético-dedutivo. Resumindo o raciocínio: "Quem rouba merece castigo. Eu não roubo. Eu não mereço castigo." E o caráter hipotético-dedutivo: "Se roubo, então mereço castigo."

Como vimos em grande quantidade de casos, o uso de conectivo "mas" significa um considerável acréscimo de qualidade na operatoriedade do pensamento; representa a introdução da capacidade de discriminar situações reais entre si, situações reais de desejos representados e, ainda, desejos apenas representados com possibilidades (realidade virtual) apenas representadas. Esta última capacidade encontra sua expressão genuína no raciocínio hipotético-dedutivo: "Se... então...", que passaremos a analisar. 
C.A.L., 14 anos, ao ser perguntado: "Como seria uma boa alimentação para ti?", responde: "Tendo um arroz, feijão, um pedaço de carne, pra mim tá bom". Parece claro que C.A.L. raciocina de acordo com o modelo hipotético-dedutivo, em nível proposicional, o que significaria a presença da capacidade operatória formal. Traduzindo: "Se tiver arroz, feijão e um pedaço de carne, então estarei bem alimentado."

C.A.L. diz que "... gostaria de ter uma casa minha, ... uma loja minha; trabalha pra mim; que eu nunca gostei de trabalha prós outros... (porque) ... se a gente tá doente um dia, a gente perde aquele dia, se a gente não pode ir naquele dia por causa de uma pessoa da família (que) morreu a gente perde um dia; e assim a gente nunca consegue nada." Interpretando: "Se eu passar a vida trabalhando para os outros, então não conseguirei nada."

A. VU., 14 anos, perguntado sobre o por quê do comportamento de outros meninos de rua, diz: "Não sei, tia... Fumam loló, fumam maconha, cheiram loló, ficam chapado, lá, ficam se arreiando no cara. Só porque são grande se arreiam no cara. Já falei pra eles: a próxima vez que se arreiarem em mim, vou mata um com um tijolo. Não quero nem sabe. Se arreiam em mim vou dá no meio da cabeça." A forma hipotética fica assim: "Se alguém deles se arreiar em mim, então eu mato com um tijolo."

N.1.O., 16 anos, raciocina: "Eu acho que se a professora botasse mais tema no caderno que no quadro ficaria melhor." Pergunta a pesquisadora:

$\mathrm{R}:-$ Por que tu teve que trabalhar?

N.I.O.:- Porque eu precisava.

$\mathrm{R}:-$ Precisava como?

N.I.O.: - Eu tinha que trabalha pra me sustentar.

$\mathrm{R}:-\mathrm{E}$, agora, o que tu faz?

N.I.O.: - Agora, eu estudo; não trabalho. Eu estudo; meu pai me sustenta.

Aí, enquanto tô estudando ele tá me sustentando.

R:- E quando tu precisa de dinheiro, aí tu trabalhas, é isso? 
N.1.O.: - Se eu precisa pra uma roupa, pra alguma coisa, aí eu trabalho. Compro com o meu dinheiro.

O raciocínio, na sua forma argumentativa simples, está claro: "Eu trabalho porque preciso de dinheiro". Ou, na forma silogística: "Quem precisa de dinheiro, trabalha. Ora, eu preciso de dinheiro. Logo, eu trabalho". Ou, ainda, na forma hipotético-dedutiva: "Se eu precisar de dinheiro, então trabalharei".

A constatação nessa análise, da presença freqüente da forma hipotético-dedutiva de raciocínio, indica, por si só, que esses sujeitos apresentam as condições mínimas necessárias, não apenas para a alfabetização no sentido estrito, assim como a escola a concebe, mas também aquelas necessárias para dar conta da escolarização fundamental, isto é, para dar conta de tudo aquilo que a escola convencional tem para ensinar. Se a escolarização não se verifica, ou não ocorre com êxito, não se pode tributar este fato à falta de capacidade cognitiva, lógica - no sentido instrumental - desses sujeitos. Este fato deve ser atribuído a outras causas, entre as quais, a incompetência da escola em ensinar.

\section{G) ARGUMENTAÇÃOCONCATENADA}

DRA., 16 anos, responde à pesquisadora:

R: - E o que tu achas que é preciso para ter saúde? DR.A.:É preciso ter higiene, tomar banho todos os dias, escova os dentes. Também é preciso não ficar mexendo no lixo... O principal, o que faz mais parte da doença é a higiene. Os micróbios, as coisas que as pessoas pegam no lixo, por exemplo,... toco assim de cigarro aí pega e bota no dedo na boca, aí tá passando todos os micróbios pra dentro da boca; e aí começa essas doenças.

Poderíamos estruturar um raciocínio simples da seguinte maneira: "Quem desrespeita normas de higiene (mexer descuidadamente no lixo, não escovar os dentes, etc.) não cuida de sua saúde. Ora, muitas pessoas desrespeitam normas de higiene (mexer no lixo, etc). Logo, muitas pessoas 
não cuidam de sua saúde." A fala de D.R.A. não contém propriamente uma argumentação concatenada, mas várias justificativas de mesmo nível para uma mesma afirmação.

NO.D., 16 anos, falando de suas agressões, responde à pesquisadora:

R:- E o teu pai, o que achava disso?

N.O.D.: - Ah, não achava nada, porque ele sabia que eu tinha que defender minhas irmãs. Eu era maior, tinha que defender minhas irmãs menor. Não achava nada. Quando eu ia expulso daquela aula, ele tirava a gente e botava minhas irmãs na outra; sempre tinha eu pra defender minhas irmãs.

O argumento simples de NO.D. é o seguinte: "Eu não era repreendido por meu pai porque eu defendia minhas irmãs". Ou, de forma mais aprofundada: "Eu devo ser justificado no meu comportamento violento, porque eu defendo minhas irmãs". Continuemos ouvindo N.O.D.:

$\mathrm{R}:-$ E como tu gostaria que fosse a escola?

N.O.D.: - Gostaria que fosse assim: cada professor tivesse uns dez alunos; atendia um, atendia outro. Não, assim, bota só tema no quadro. Só no quadro vai um tempo que a gente enjoa, tá escrevendo só do quadro, só do quadro.

Coloquemos este raciocínio na forma hipotético-dedutiva: "Se o professor tiver poucos alunos, então poderá fazer atendimento individual. Se o professor fizer atendimento individual, então sua aula será interessante". Como se vê, trata-se de um raciocínio composto, de nível operatório formal. Continuemos com a fala de NO.D., sobre violência policial:

R: - Tu consideras isso como uma forma de violência com as pessoas?

N.O.D.: - Eu acho que sim, porque tu não tá fazendo nada. Eles pegam e saem batendo nas pessoas, eu acho que não é certo. Nem sabem quem é a pessoa, eles ficam batendo... Saem batendo não interessa pra eles quem é, quem não é.

O argumento parece ter a seguinte forma: "A polícia é violenta porque bate nas pessoas. A polícia bate nas pessoas porque desconhece as pessoas". Tentemos uma forma de argumentação utilizando somente a 
premissa maior e a conclusão: "Quem bate nas pessoas é violento. Logo, a polícia é violenta. Quem desconhece as pessoas bate nas pessoas. Logo, a polícia bate nas pessoas". O raciocínio é formalmente correto. O conteúdo da segunda premissa maior, porém, não é sustentável.

Como vimos, a análise da atividade congnitiva dos sujeitos desta pesquisa dá conta de que eles não apresentam déficit cognitivo e, além disso, apresentam performance lógico-instrumental capaz de dar conta de tudo o que a escola fundamental tem para lhes ensinar. Os problemas que eles apresentam - parece-nos — são de ordem diversa dos problemas cognitivos. São problemas sócio-afetivos: desconfiança generalizada das pessoas que não fazem parte de sua "gang"; confiança extremada em suas lideranças; rejeição familiar de toda ordem; rejeição social de toda ordem; comportamento paranóides desenvolvidos devido à freqüente perseguição policial, ao rechaço da parte de vigilantes de lojas, à atitude hostil de cidadãos comuns; incapacidade, devido a esses fatores, de suportar a disciplina escolar; atitudes estraordinariamente agressivas frente a professores. Enfim, esses sujeitos constróem uma capacidade cognitiva impregnada por uma cultura de exclusão. Eles constroem uma capacidade lógico-formal com a qual poderiam apropriar-se dos bens da cultura mais elaborada, mas com esta mesma capacidade eles estruturam a sua identidade de excluídos. A mesma capacidade que poderia concorrer para libertá-los acaba servindo para estruturar sua vida de excluídos - e, de certa forma, preservar sua identidade. A condição apriori da assimilação da cultura elaborada (ciências, artes, filosofia, matemática, etc.) foi por eles construída. Os espaços sociais onde é possível o contato com essas instâncias da cultura elaborada estão quase todos fechados. Seu acesso a esses espaços é proibido, sua palavra não é ouvida, sua presença física é rechaçada, sua presença simbólica (de classe) é rejeitada, quase sem concessões. Eles fazem parte dos excluídos dessa sociedade.

Como a escola formal poderá organizar-se para dar conta dessa situação? A escola que pensar seriamente nisso deverá, antes de qualquer coisa, assumir essa cultura da exclusão com a linguagem que lhe é própria; esforçar-se por compreendê-la em toda a sua dramática extensão, e, em função dessa compreensão, repensar, juntamente com seus sujeitos, todo 
o currículo escolar. A cultura da exclusão será a matéria prima de qualquer projeto educacional que quiser enfrentar essa realidade; a interação com o "acervo cultural da humanidade" deverá ocorrer a partir desse pressuposto. $\mathrm{O}$ que fugir disso não passará de assistencialismo paternalista/ maternalista que só fará recrudescer ainda mais essa terrível realidade.

Sob o ponto de vista da epistemologia genética piagetiana e da pedagogia freireana, é esse o caminho capaz de recuperar o significado do processo de construção do conhecimento, por um lado, e da relação pedagógica fecunda, por outro; sobretudo, quando o ato pedagógico envolve sujeitos tão brutalmente atingidos, também cognitivamente, por um sistema econômico e social injusto. Significa que a ação pedagógica voltada a essa realidade deve ser radicalmente ativa, tanto para o educador quanto para os sujeitos da aprendizagem. Ativa no sentido da tomada de consciência e da conscientização, da equilibração e da abstração reflexionante, da educação libertadora, enfim. Pensamos, aqui, numa escola que tem como marca fundamental a recuperação, no seu mais radical sentido, da palavra do educando; ou seja, a recuperação do significado profundo da vida do sujeito da aprendizagem, isto é, do seu ser numa sociedade humana historicamente situada.

\section{Referências bibliográficas}

BECKER, Fernando. Ensino e construção do conhecimento: o processo de abstracão reflexionante. Educação e Realidade, Porto Alegre, v. 18, n. 1, p.43-52,1993.

Modelos pedagógicos e modelos epistemológicos. Educação e Realidade, Porto Alegre, v.19, n.1, p.89-96, jan./jun., 1994.

BULGARELLI, Reinaldo. DocumentoMNMMR. [S.1., 19-]. mimeo . É possível educar na rua? Projeto alternativo de atendimento aos meninos de rua. [S.1.]: FUNABEM/UNICEF, SAS, 1987.

CAMPOS, Angela Valadares Dutra de Souza. Um menor institucionalizado: um desafio para sociedade. Petrópolis: Vozes, 1984.

CHAUI, Marilena. Conformismo e resistência: aspectos da cultura popular no Brasil. São Paulo: Brasiliense, 1989. 
DIMENSTEIN, Gilberto. A guerra dos meninos: assassinatos de menores no Brasil. São Paulo: Brasiliense, 1990.

abr., lys/.

. A fabricação do menor. Humanidades, Brasília, fev./

Cortez, 1985.

_. Saber profissional, poder institucional. São Paulo:

FERREIRA, Rosa Maria Fischer. Meninos de rua: expectativas e valores de menores marginalizados em São Paulo. São Paulo: CEDEC: IBREX, 1979.

FOUCAULT, M. Microfisica do poder.4.ed. Rio de Janeiro: Graal, 1984.

FREIRE, Paulo. Educação como prática da liberdade.6.ed. Rio de Janeiro: Paz e Terra, p. 150, 1976.

. Conscientização; teoria e prática da libertação; uma introdução ao pensamento de Paulo Freire. São Paulo: Cortez \& Moraes, 1979a. 102n.

. Educação e mudança. Rio de Janeiro: Paz e Terra, 1979b.79p. T979c 218p.

. Pedagogia do Oprimido.6.ed. Rio de Janeiro: Paz e Terra,

Conscientização. São Paulo: Cortez \& Moraes, 1989.

. Pedagogia da esperança; um reencontro com a pedagogia do oprimido. Rio de Janeiro: Paz e Terra, 1992.

FREIRE, Paulo et al. Uma abordagem crítica- projeto Alternativas Comunitárias de Atendimento a Meninos de Rua. [S.1.]: UNICEF: SAS: FUNABEM, 1980. rus, 1987.

. Fazer escola conhecendo a vida.3.ed. Campinas: Papy-

FREITAS, Conceição. Movimento Nacional de Meninos e Meninas de Rua: realidade de crianças e adolescentes no Brasil, mimeo.

GALEANO, Eduardo. Ser como eles. Nossa América. 1991.

GIROUX, Henry. Teoria crítica e resistência em educação: para além das teorias da reprodução. Rio de Janeiro: Ed. Petrópolis, 1986.

IBASE. Vidas em risco: assassinatos de crianças e adolescentes. Rio de Janeiro: MNMMR/NEU/USP, 1991.

INHELDER, Barbei, PIAGET, Jean. Da lógica da criança à lógica do adolescente. São Paulo: Pioneira, 1976.26T)p. 
KOWARICK, Lúcio. A espoliação urbana A.ed. Rio de Janeiro: Paz e Terra, 1985.

Janeiro: Paz e Terra, 1979.

.Capitalismo e marginalidade na América Latina. Rio de

----Paze Terra, 1985.

São Paulo:

LUIZ, José Luís Brandão da. A imaginação e a criatividade na teoria piagetiana do desenvolvimento da inteligência. Educação e Realidade, Porto Alegre, v. 19, n.1, p.61-70, jan./jun., 1994.

MACEDO, Lino de. O construtivismo e sua função educacional. Educação e Realidade, Porto Alegre, v.18, n.1, p.25-31, jan./jun., 1993.

MACIEL, Marina, CARDOSO, Gomes Franci. Metodologia do serviço social: a praxis como base conceitual. ABESS, n.3, 1989.

MARTINS, José de Souza. O massacre dos inocentes: a criança sem infância no Brasil. São Paulo: Hucitec, 1991.

MATTA, Roberto da. Carnavais, malandros e heróis: para uma sociologia do dilema brasileiro.4.ed. Rio de Janeiro: Zahar, 1983.

PIAGET, Jean. A noção de tempo na criança. Rio de Janeiro: Record, 1946. 32 lp.

. Études d 'èpistémologie génétique. La logique des apprentissages. Paris: P.U.F., 1959, v.10,p.159-88: Apprentissage et connaissance (seconde partie).

--- $1972 . \overline{12} 9 \mathrm{p}$.

Psicologia da inteligência.2.ed. Rio de Janeiro: Fundo de Cultura,

Biologia e conhecimento: ensaio sobre as relações entre as regulações orgânicas e os processos cognoscitivos. Petrópolis: Vozes, 1973a. 423p.

I . Estudos sociológicos. Rio de Janeiro: Forense, 1973b. 23 lp.

Aprendizagem e conhecimento (primeira parte). In: PIAGET, Jean, GRECO, Pierre. Aprendizagem e conhecimento. Rio de Janeiro: Freitas Bastos, 1974. p.33-91. (E.EG., 7).

.Para onde vai a educação.2.ed. Rio de Janeiro: J. Olympio, 1975.

89 p.

. Psicologia e pedagogia A.ed. Rio de Janeiro: Forense, 1976.184p. 
. O julgamento moral na criança. São Paulo: Mestre Jou, 1977.358p.

. Fazer e compreender. São Paulo: Melhoramentos: EDUSP, 1978a.

$186 \mathrm{p}$.

. A Formação do símbolo na criança; imitação., jogo e sonho imagem e representação.3.ed. Rio de Janeiro: Zahar, 1978b. 370p.

. A tomada de consciência. São Paulo: Melhoramentos: EDUSP

1978c. $21 \mathrm{lp}$.

A construção do real na criança.3.ed. Rio de Janeiro: Zahar 19/9.360p.

, INHELDER, Barbei. Gênese das estruturas lógicas ele mentares.2.ed. Rio de Janeiro: Zahar, 1979. 360p.

INHELDER, Barbei. La representation de l 'espace chez / 'enfantA.ed. Paris: Press Universitaires de France, 1981. 574p.

et al. Recherches sur là contradiction. Paris: P.U.F., 1974, v.2, p.153-178: Conclusions generales.

et al. Recherches sur Vabstraction réfléchissante. Paris: P.U.F., 1977. v.2, p.303-324: Conclusions generales.

UNICEF. Situação mundial da infância. 1993. p.55.

VALORES de Menores Marginalizados. Revista SP, São Paulo: EEDEC/BREX, 1979.

VELASCO, Jesus Martinez. Lenguaje y congnición: entre nativismo y construetivismo. Educação e Realidade, Porto Alegre, v.19, n.1, p.7-28, jan./jun. 1994.

VIOLANTE, Maria Lúcia. O dilema do discente malandro.4.ed. São Paulo. Cortez, 1985.

ZIEBELL, Clair et al. Relatório Projeto Educação Zonal de Rua. [S.l.: 19-]. mimeo

Recebido em 29 de março de 1994.

Clair Ribeiro Ziebell, especialista em Metodologia do Ensino Superior pela Universidade Católica de Pelotas (UCPEL), é mestranda em Educação Básica na Universidade do Vale do Rio dos Sinos (Unisinos). 
Fernando Becker, doutor em Psicologia Escolar pela Universidade de São Paulo (USP), é professor titular de Psicologia da Educação da Faculdade de Educação da Universidade Federal do Rio Grande do Sul (UFRGS).

This research aims to investigate, first, what street children know )outfamily, education-school, wealth-poverty, health-disease, FEBEM Children care governmental institution), justice courts, police, violence, vage-work. Secondly, it aims to investigate how they think, that is, their rganization capacity on these knowledges or their logic. The analysis of the first topic reveals expressions, feelings and behaviors such as acceptation, criticism, indignation, passiveness, mockery, angriness, hate, sadness, affection, disaffection, denouncement ofperplexity on social realty. Using Jean Piaget 's Genetic Epistemology and formal logic, the analy-s of the second topic is guided by the categories: narration ofactions, me control, fragments - totality, assertion followed by an adversative onjunction, hypolhetical-deductive reasoning, concatenate argumentaon. Combining Piaget 's Genetic Epistemology and Paulo Freire s Pedaogics this research has tried to outline the assumptions for a pa th cambie to recover the meaning of the knowledge construction process on one hand, and of a rich pedagogical relationship, on the other, aiming the school educational process, specifically basic instruction for these subjects.

Cette investigation veut chercher, dans un premier moment, ce que les enfants de rue pensent sur là famille, éducation-école, richessepauvreté, santé-maladie, FEBEM (institution gouvernementale daideà 'enfance), tribunauxpour enfants, police, violence, salaire-travail. Dans $n$ deuxième moment, elle essaye de rechercher comme ils pensent, $c$ 'est-dire, leur capacite d 'organisation de ces connaissances ou leur logique. 'analyse du premier thème revele des expressions, sentiments et omportements comme: acceptation, critique, revolte, passivité, ironie, age, haine, tristesse, affection, désaffection, dénonciation de perplexité 
devant là réalité sociale. $L$ 'analyse du deuxième thème, employant de l 'Épistémologie Genétique de Piaget et de là logique formate, est orientée par les categories: narraíion des actions, controle du temps, fragments - totalité, affirmotion suivie d 'une conjonction adversative, raisonnement hypothético-déductif argumentation enchainée. Cette recherche essaya, par les voies combinées de l 'épistémologie genétique de Piaget et de là pédagogie de Paulo Freire, de tracer les présuppositions d'un chemin capable de retrouver le signifié du procede de construction de là connaissance, d'un côté, et du rapport pédagogiquefécond, d'autre, pour le procede educational à l 'école, spècifiquement d'alphabètisation de ces sujets.

Esta investigación trata, en un primer momento, de rastrear Io que saben los ninos callejeros sobre familia, educación-escuela, riquezapobreza, salud-enfermedad, FEBEM (Institución de atención al menor), juzgado de menores, policia, violência, sueldo-trabajo. En un segundo momento, busca investigar como ellos piensan, o sea, su capacidad de organización de esos saberes o su lógica. El análisis del primer tema revela expresiones, sentimientosy comportamientos de aceptación, crítica, sublevación, pasividad, ironia, ódio, tristeza, afecto, desafecto, denuncia de perp lex idadante là realidad social. El análisis del segundo, valiéndose de Ia Epistemologia Genética de Piaget y de là lógica formal, se orienta a través de Ias categorias: narrativa de acciones, control del tiempo, fragmentos - totalidad, afirmación seguida de conjunción adversativa, razonamiento hipotético-deductivo, argumentación concatenada. Esta investigación busco, por Ias vias combinadas de là Epistemologia Genética de Piaget y là Pedagogia de Paulo Freire, delinear los presupuestos de un camino capaz de recuperar el significado del proceso de construcción del conocimiento, por un lado, y de là relación pedagógica fecunda, por otro, para un proceso educacional escolar, especificamente de alfabetización de esos sujetos. 